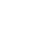

\section{Introducing Competition and Deregulating the British Domestic Energy Markets: a Legal and Economic Discussion}

\author{
by \\ Michael Harker \\ ESRC Centre for Competition Policy and Norwich Law School, \\ University of East Anglia \\ \& \\ Catherine Waddams Price \\ ESRC Centre for Competition Policy and Norwich Business \\ School, University of East Anglia
}

\section{CCP Working Paper 06-20}

\begin{abstract}
In this article we chart the development of competition and deregulation of the British retail energy markets, explaining the evolution of competitive constraints when consumers are introduced to supplier choice for the first time. In the context of rising real energy prices for consumers, and continued market power on the part of incumbents, we address the question of whether the control of pricing practices through the ex post provisions of the general competition law is sufficient to protect consumers. We also explore the issue of whether reliance solely on these provisions is desirable given the uncertainty which surrounds the application of the Chapter II prohibition (governing abuse of dominance), specifically in respect of price discrimination in final markets. We conclude that the outcome of the liberalisation experiment in terms of delivering benefits for consumers is unclear.
\end{abstract}

November 2006

JEL Classification Codes: K21, K23, I38, L12, L41, L51, L94, L95.

Keywords: energy markets, deregulation, monopoly, competition, dominance, market power, consumer switching, switching behaviour, price rebalancing, ex post and ex ante regulation. 


\section{Acknowledgements:}

The authors thank Morten Hviid for commenting on a draft of this article. An early draft was presented at the Conference on the Pros and Cons of Antitrust in Deregulated Markets, Swedish Competition Authority, in November 2004 (for the conference proceedings see: Bergmann and Nilsson (eds.) The Pros and Cons of Antitrust in Deregulated Markets (Stockholm, Sweden: Swedish Competition Authority, 2004)). Thanks go to the participants of that conference and to the discussant, Maureen Ohlhausen, for their helpful comments and insights. All errors and omissions are the responsibility of the authors. The support of the Economic and Social Research Council is also gratefully acknowledged.

\section{Contact details:}

Michael Harker, Centre for Competition Policy, University of East Anglia, Norwich, NR4 7TJ, UK.

m.harker@uea.ac.uk

Catherine Waddams Price, Centre for Competition Policy, University of East Anglia, Norwich, NR4 7TJ, UK.

c.waddams@uea.ac.uk 


\section{Introduction}

Antitrust institutions are designed principally to protect consumers from abuse of market power. Competition law and policy is concerned with the identification of competitive constraints which prevent a firm or a group of firms from exploiting single or joint dominance in a market, and to develop potential remedies when such constraints are absent or ineffective.

Focusing on the British residential energy markets, we chart the development of market opening and regulatory policy from the introduction of competition to the present, and we explore the evolution of competitive constraints when consumers are able to exercise choice of suppliers in a market for the first time. The process of opening residential energy markets to competition was controversial, with some commentators questioning beforehand whether the benefits would outweigh the costs. ${ }^{1}$ Introducing competition in retail energy markets is justified if it reduces costs and prices below the level which the regulated monopoly can achieve, or engenders innovation among firms which is beneficial to consumers. Even if costs are reduced by the competitive process, if the unregulated market includes significant levels of market power, consumers as a whole may be worse off if price levels rise as a consequence. $^{2}$ Furthermore, if regulation is withdrawn prematurely, firms may be able to exercise market power (either individually or jointly) to raise prices. The ability to do so depends in part upon whether control through the ex post provisions of the general competition law is sufficient to protect consumers or whether there was or is a case for a continuation or reinstatement of ex ante controls. In the context of rising real prices for consumers, and continued market power on the part of incumbents, we explore these issues.

The energy market is politically sensitive. Consumer advocacy has been and continues to be an important feature of the regulatory environment. Academic literature and policy initiatives increasingly recognise the central role of consumers in competition policy. ${ }^{3}$ Consumers have the power of 'voice' in markets which are politically sensitive, and this affects both the operation of the market and the institutions which regulate it. Consumers also have the more traditional option of 'exit' (i.e., choosing an alternative supplier) if an incumbent supplier attempts to exploit them. ${ }^{4}$

As a consequence of strong consumer 'voice', deregulation has been a subtle process; there is ample evidence both from the prices charged, and from

\footnotetext{
${ }^{1}$ Green, R and T. McDaniel "Competition in electricity supply: will 1998 be worth it?" (1998) 19(3) Fiscal Studies 273-294.

${ }^{2}$ In some cases, total surplus might increase, but suppliers might benefit at the expense of consumers. For a full discussion of these issues, including the distributional impact of competition, see: Waddams Price, C. "Social Consequences of Energy Market Liberalisation in the UK" (2005) 21(1) Oxford Review of Economic Policy 128-144.

${ }^{3}$ For a recent discussion see: Howells, G., "The Potential and Limits of Consumer Empowerment by Information" (2005) 32(3) JLS 349; Waterson, M. "The role of consumers in competition and competition policy" (2003) 21(2) International Journal of Industrial Organization 129-150. On the OFT's coordinating role, see: OFT, A Strategy and Framework for Consumer Education: A Consultation Paper, (London: OFT, 2004).

${ }^{4}$ This characterisation of consumer empowerment derives from Hirschman, A.O., Exit, Voice and Loyalty, Responses to Decline in Firms, Organizations and States (Cambridge MA: Harvard University Press).
} 
interviews with companies, that they are very conscious of potential adverse publicity from consumer watchdogs or the general media to any changes which might be seen as disadvantaging vulnerable consumers. ${ }^{5}$ It is arguable, therefore, that in practice the sector is only partially deregulated, in the sense that while formal ex ante regulation has been removed, the companies still act under the shadow of both potential regulatory intervention and public opprobrium. We question whether in the long-term a model of tacit regulation is preferable to one which provides dominant firms with clear and consistent principles governing their behaviour.

In the following section we offer a brief historical perspective on the deregulation of the residential energy supply market, sketching the relevant regulatory institutions, and discussing further the distributional concerns which attach to prices and their rebalancing. Section 3 discusses two characteristics which affect the dynamics of competition in this market: consumer switching costs and (single and joint firm) dominance. Section 4 charts the deregulation of the sector and highlights the emergence of principles which were largely derived from the general competition law but applied through ex ante controls. Section 5 examines the current situation questioning whether full deregulation in respect of pricing practices was appropriate given the uncertainty which surrounds the application of the general competition law to this sector. Section 6 concludes.

\section{The British energy market: the history of deregulation, the institutions of regulation and the role of consumer "voice"}

The British residential energy markets were opened to competition between 1996 and 1999. The gas industry had been privatised in 1986 as a vertically integrated company with a monopoly in supply throughout Great Britain. Although competition in the residential markets was not envisaged at privatisation, the Government announced its advent in 1994. By the time choice of gas supplier was introduced for the first consumers in south west England in 1996, the retail arm was effectively independent of the pipeline ownership (though full demerger did not occur until the following year). Gas choice was introduced over two years on a regional basis. ${ }^{6}$

The experience and learning from the introduction of gas competition over two years enabled a much faster opening of the residential electricity market introduced over eight months in 1998-99. Unlike gas, the introduction of competition had been anticipated at privatisation in 1990. Of the fourteen regionally-based incumbent monopolists, there were two Scottish companies who were vertically integrated (with retail, transmission and distribution and generation owned by the incumbent) and twelve incumbents in England and

\footnotetext{
${ }^{5}$ Sharratt, D. and C. Waddams Price, "Deregulating Prices and Social Obligations, Company Policy and Outcomes", mimeo, University of East Anglia, 2003.

${ }^{6}$ Starting with half a million consumers in the south west England in May 1996, followed by another one and a half million in the south of England later that year, and with all residential consumers able to choose their gas supplier within two years of the initial experiment.
} 
Wales (who were integrated distribution and retail companies, and who have developed generation capacity post-privatisation). ${ }^{7}$

The institutions of regulatory control are based primarily on the need for economic regulation of the parts of the industries where monopoly is endemic or where competition has not developed sufficiently. A single regulator, the Office of Gas and Electricity Markets (Ofgem), with oversight of the two markets, was created from the merger of the Office of Gas Regulation (Ofgas) and the Office of Electricity Regulation (Offer) in 1999. To protect consumers from potential abuse of monopoly power, the retail energy markets were subject to ex ante price controls (contained in the firms' licences), which the regulator gradually rolled back from the introduction of competition until they were removed completely in 2002.

The regulators' roles were originally defined in the privatisation statutes (Gas Act 1986 and Electricity Act 1989) but were significantly changed by the Utilities Act 2000. ${ }^{8}$ The 2000 Act gave Ofgem a new primary duty of protecting consumers "wherever appropriate by promoting effective competition". ${ }^{9}$ One of its new secondary duties was to take account of the needs of low income consumers, a group added to similar responsibilities previously held for those of pensionable age, the chronically sick and disabled and those in rural areas. Also created was an independent sectoral consumer 'watchdog', energywatch, with responsibilities for providing information on the market to consumers, as well as for representing and championing their interests. ${ }^{10}$ While the Act preserves the 'arms-length' relationship between the regulator and government, the latter is entitled to issue guidance to the regulator on social and environmental issues. ${ }^{11}$

With the removal of price controls, the pricing practices of firms supplying residential markets are subject only to the provisions of the Competition Act 1998. ${ }^{12}$ Since the Act came into force in March 2000, most of the UK sectoral regulators (including Ofgem) enjoy concurrent powers with the Office of Fair Trading (OFT) to apply the Act's provisions to their industry sectors. At the heart of the Act are the Chapters I and II prohibitions (modelled on Articles 81 and 82 of the EC Treaty respectively). ${ }^{13}$ There is a close relationship between the UK and EC prohibitions: all bodies charged with the application and enforcement of the UK prohibitions are required to do so in a manner which is consistent with the application of EC law. ${ }^{14}$ This is particularly important in the

\footnotetext{
${ }^{7}$ From 2001, changes in licensing rules provided for the separate ownership of the distribution and supply functions.

${ }^{8}$ For a full discussion of the debate leading up to the Utilities Act, see: Harker, M. "Regulation, consumer protection and the law" (1998) 20(3) Journal Social Welfare \& Family Law, 324.

${ }^{9}$ Gas Act 1986, s.3A; Electricity Act 1989, s.4AA.

${ }^{10}$ For a full discussion of utility consumer bodies, see Harker, M, L. Mathieu and C. Waddams Price, "Regulation and Consumer Protection" in M. Crew and D. Parker (eds), International Handbook of Economic Regulation (Cheltenham and Northampton MA: Edward Elgar, 2006).

${ }^{11}$ Gas Act 1986, s.3A; Electricity Act 1989, s.4AA.

12 Regulatory controls remain in respect of many other of the firms practices and obligations, however.

${ }^{13}$ The Chapter I prohibition makes prima facie unlawful agreements or concerted practices which have the object or effect of preventing, restricting or distorting competition. The Chapter II prohibition makes conduct which amounts to an abuse of a dominant position unlawful.

${ }^{14}$ Competition Act 1998, s. 60.
} 
energy sector where there is little UK case law to act as a guide to the interpretation of the prohibitions.

The energy sector is politically sensitive; one of the reasons for privatisation was to remove it from the political interference to which it had been subject over the previous twenty years, including on the level and structure of retail prices and the choice of fuels for generation plants. ${ }^{15}$ The sector is crucial to the smooth running of the economy and communications, with importance well above the two per cent it contributes to GDP.

There are important low income issues at the retail level (now reflected in the regulator's duties) because, although consumption increases with income, it does so at a decreasing rate, so that low income households spend a much higher proportion of their income on energy than do higher income groups. This issue has been emphasised by the development in the UK of a crossdepartmental government initiative on reducing the incidence of fuel poverty. The Government are committed to eliminating fuel poverty in vulnerable households by 2010. ${ }^{16}$ A household is defined as being in fuel poverty if it spends, or needs to spend, more than 10 per cent of its income on household energy requirements; vulnerable households are those containing children or those who are elderly, disabled or long-term sick. There has been considerable concern about households who are disconnected from supply because of non-payment of bills. Since privatisation there has been a significant increase in the use of prepayment meters which firms have used as an alternative to disconnection for consumers in debt. For that reason, there are a disproportionate number of low income consumers who use this form of payment as compared with others.

Due to its strategic importance to the economy and distributional concerns, the sector continues to attract considerable political interest, despite the ambitions that privatisation and independent regulation would reduce the likelihood of politicisation. These conditions give rise to a strong, though not always representative, nor objectively argued, consumer voice.

Prices in this context have always been controversial. The privatised industries inherited from their nationalised predecessors a pricing system broadly based on average costs, which was concerned more about the total revenue than how it was collected from different groups of consumers. The emphasis had been on universal access, rather than on reflecting costs for different consumer groups. Consumers with higher than average costs were generally subsidised by those with lower costs. ${ }^{17}$ Such uniform pricing could not survive the introduction of competition in retail supply, since entrants

\footnotetext{
${ }^{15}$ On this point, see in particular Prosser, T., Nationalised Industries and Public Control (London: Blackwell, 1986).

${ }^{16}$ DTI, UK Fuel Poverty Strategy (London: TSO, 2001). Under the Warm Homes and Energy Conservation Act 2000 the Secretary of State is required to publish and implement a strategy to reduce fuel poverty including the setting of targets.

${ }^{17}$ For example, the higher costs of distribution to rural consumers are not reflected in the uniform distribution charges within each area, so that rural users are subsidised by those in urban areas; such cross subsidy is sustainable so long as the regional distribution network remains a monopoly and can recover its total costs.
} 
would target the lower cost, higher margin, consumers. The incumbent would either lose these consumers or have to lower its prices to retain them; in either case their higher margin would no longer be available to subsidise the higher cost consumers, whose prices would have to rise if the incumbent were not to face financial difficulties.

Cross-subsidies were present in two further significant aspects of the retail energy market before competition was introduced: in payment method, where companies argued that the additional costs of collecting frequent cash payment, relative to those of automated bank debits, were not adequately reflected in the price differential for these two methods of payment; and in the balance between the fixed ('standing') charge relative to the charges related to consumption, the former not reflecting the full fixed costs of retail service (i.e., costs independent of the amount of energy consumed). Rebalancing these elements of the tariff would harm those who used prepayment (predominantly lower income households) and those who used less energy (again more low income than high income consumers). The introduction of competition was therefore socially and politically controversial because of its potential effect on vulnerable households. ${ }^{18}$ Against this background it is hardly surprising that political interest in the sector remains high.

\section{Consumer switching and market power in retail energy supply}

In this section, we discuss the economic characteristics of the retail energy market. As is shown below, incumbent firms retain high market shares, despite charging significant price premia over entrants. This may be indicative of switching costs (real or perceived) having a significant effect on the behaviour of consumers in this market and, therefore, on the dynamics of competition. We review the empirical evidence on switching costs and discuss some of the effects such costs may have on the market power of dominant firms.

\section{(a) Consumer switching behaviour}

Switching costs are disadvantages which a consumer perceives would be incurred by changing to another supplier, but not by staying with the current supplier. Such costs may be financial (a better deal as a reward for loyalty with the current supplier, or a charge to change supplier), involve the consumer's time (in searching or switching) or be psychological (concern or uncertainty about the quality of service from a new provider).

In retail energy there are no financial costs of changing supplier, and the physical product is homogeneous, although the terms of its offering are not. The markets are generally mature, ${ }^{19}$ with no history of consumer choice before the introduction of competition. Upon privatisation, the incumbents

\footnotetext{
${ }^{18}$ For a full discussion of the distributional impact of tariff rebalancing see: Ernst, J., Whose Utility? The Social Impact of Public Utility Privatization and Regulation in Britain (Buckingham: OUP, 1994); Corry, D., C. Hewitt and S. Tindale (eds), Energy '98: Competing for Power (London: Institute for Public Policy Research, 1996).

${ }^{19}$ Virtually all households are connected to the electricity network, and around 80 per cent to gas (although there is some expansion of the gas network in rural areas).
} 
inherited 100 per cent of their respective markets (there was no ex ante division of the market between incumbent and entrants as in some US States).

Suppliers are required to offer general tariffs for three forms of payment: prepayment (where the supply of energy is activated through insertion of an electronic card recording advanced payment); quarterly standard credit terms; and monthly automated deductions from bank accounts (direct debit). ${ }^{20}$ Information about these tariffs is made generally available through the consumer watchdog, energywatch and other affiliated third party sources. Each consumer has the right to change provider with 28 days' notice to his existing supplier, though suppliers can object to the exit of consumers in debt and consumers may contract with their supplier for a fixed term.

It is helpful to see how this market has evolved from consumer studies which reported progress at various stages of the liberalisation project. Waddams Price and Bennett examined early trends in gas switching in the south west of England, when the concept was very new. ${ }^{21}$ At this very early stage, the targeting of more profitable customers and tariff rebalancing was already evident. The conceptualisation of choice was itself problematic: consumers found it difficult to distinguish the supply of energy from the pipes and wires through which it was conveyed. In another survey of consumers about eight months after the gas market was fully opened to competition (early 1999), Giulietti et al. posited that switching behaviour was best explained through a two-stage decision model where awareness of the ability to switch and switching itself are modelled simultaneously. ${ }^{22}$ Search costs were found to be a barrier for many consumers, particularly those who had no switching experience in other similar markets; and switching costs were perceived to be high (relative to the reality) in terms of the time it would take. Those of pensionable age and using prepayment meters were less likely to be aware of the possibility of switching and those in rural areas less likely to make the change. Willingness to consider switching increased with income, but at a decreasing rate. Respondents were more likely to consider switching if the best entrant offer relative to incumbent charges (for their payment type and consumption level) was high and if they expected that the incumbent was reluctant to match these savings, i.e., they expected the benefits of switching to last for some time. Most of the respondents, particularly those who did not switch, were optimistic that the incumbent would match the entrants' lower prices. Such expectations confer considerable market power on the incumbents (and, as is shown below, are largely misplaced). Overall, Giulietti et al. found that search costs and perceived (rather than actual) switching costs were the main barriers to more active consumers. Later research has indicated that, despite the apparent simplicity of the product and the transparent nature of the market, consumers who do switch sometimes do so to their detriment. ${ }^{23}$

\footnotetext{
${ }^{20}$ In addition, British Gas has offered discounts for prompt payment against the standard tariff.

${ }^{21}$ Waddams Price, C. and M .Bennett, "New gas in old pipes" (1999) 8 Energy Policy 1-15.

${ }_{22}$ Giulietti, M., C. Waddams Price and M. Waterson, "Consumer Choice and Industrial Policy: a study of UK energy markets" (2005) 115 The Economic Journal 949-968

${ }^{23}$ Wilson, C.M. and C. Waddams Price, Irrationality in Consumers' Switching Decisions: When More

Firms May Mean Less Benefit, ESRC Centre for Competition Policy Working Paper 05-4
} 


\section{(b) The pricing behaviour of incumbents and entrants}

Antitrust issues in residential energy supply markets centre around two concerns: single and joint firm dominance. We explore each in turn here. The entrants into both gas and electricity markets have been predominantly other energy suppliers, with some fringe entrants who have remained very small or have been absorbed into larger suppliers. Consolidation in the industry, mainly by takeover, has led to the domination of both the national gas and regional electricity markets by six main players, the gas incumbent and five descendents of the regional electricity incumbents. ${ }^{24}$ Table 1 shows the division of customers between these six players.

Table 1: Percentage of customers supplied by energy retailers, September $2005^{25}$

\begin{tabular}{|l|l|l|l|}
\hline Supplier & $\begin{array}{l}\text { Gas } \\
\text { market }\end{array}$ & $\begin{array}{l}\text { National } \\
\text { electricity market }\end{array}$ & $\begin{array}{l}\text { In region where } \\
\text { electricity retailer is } \\
\text { incumbent }\end{array}$ \\
\hline British Gas & 53 & 22 & n.a. \\
\hline Powergen & 14 & 20 & 51 \\
\hline Npower & 9 & 15 & 49 \\
\hline EDF Energy & 5 & 13 & 58 \\
\hline $\begin{array}{l}\text { Southern and } \\
\text { Scottish } \\
\text { Energy }\end{array}$ & 10 & 16 & 69 \\
\hline Scottish Power & 9 & 13 & \\
\hline Others & 0 & 1 & 59 \\
\hline
\end{tabular}

\# group percentage, unweighted average across regions; n.a. = not applicable

The incumbent in each market has therefore retained considerable market share and is able to charge a significant price premium over entrants in its own historical market (see table 2).

Table 2: Maximum and median price premia of incumbent over entrants, October $\mathbf{2 0 0 6}^{\mathbf{2 6}} \%$ mark-up for consumer with medium demand (20,500 kWh per year for gas and $3300 \mathrm{kWh}$ per year for electricity)

\begin{tabular}{|l|l|l|l|l|l|l|}
\hline \multirow{2}{*}{ Incumbent Supplier } & \multicolumn{3}{l|}{ Direct Debit } & \multicolumn{2}{l|}{ Standard Credit } & \multicolumn{2}{l|}{ Prepayment } \\
\cline { 2 - 8 } & Max & Med & Max & Med & Max & Med \\
\hline Bristish Gas & 19.4 & 2.6 & 23.5 & 10.2 & 17.0 & 5.4 \\
\hline Powergen & 22.0 & 16.2 & 19.1 & 10.8 & 16.6 & 8.3 \\
\hline Npower & 23.4 & 18.9 & 21.9 & 12.1 & 25.4 & 16.9 \\
\hline EDF & 13.7 & 2.5 & 10.4 & -0.5 & 6.5 & -0.5 \\
\hline Southern Scottish & 3.2 & -9.1 & 1.2 & -7.8 & 3.7 & -4.8 \\
\hline Scottish Power & 10.8 & -1.3 & 13.8 & 2.9 & 12.5 & 2.4 \\
\hline
\end{tabular}

\footnotetext{
${ }^{24}$ Ofgem has adopted consistently a regional rather than national market definition for electricity; see most recently: Ofgem, Domestic Competitive Market Review - a review document (London: Ofgem, 2004), paras. 6.22 to 6.25 .

${ }_{25}$ Ofgem, Domestic Retail Market Report - September 2005 (London: Ofgem, 2006).

${ }^{26}$ energywatch price sheets for April 2006 and own calculations allowing for subsequent price rises. While some of the percentages are negative, these probably are not indicative of trend in incumbents lowering their prices relative to entrants offers since prices are currently in a state of flux.
} 
The first competition concern is that the incumbent may remain dominant, with the potential to abuse its market power, because consumers do not exert a sufficient competitive constraint on the firm through their willingness to change suppliers. As was discussed above, upon the opening of the market to competition, consumers had little experience of choice and may have perceived switching costs (i.e., search or the transactions costs of changing supplier) as too high relative to the potential gains from switching. In this respect, both the empirical evidence and the experience suggest that there was and, indeed, there remains some cause for concern. Very shortly after the introduction of competition, Giulietti et al. asked gas consumers what price saving they would need to switch suppliers and from these figures it was clear that the profit-maximising strategy for the gas incumbent was to keep prices around $£ 100$ a year above that of competitors, thereby exploiting consumers who required larger savings to switch. Even though this would mean losing about 45 per cent of the market, the profits from the remaining 55 per cent would still render this profit-maximising. In a similar exercise for electricity, Waterson found a similar mark up would be profitable. ${ }^{27}$ We note from tables 1 and 2 that most incumbents do indeed retain just over 50 per cent of their market, while charging a significant price premium over entrants.

Consumers who are reluctant to switch suppliers may contribute to the sustainability of coordinated effects. Coordinated effects may occur in markets where "...the structure may be such that firms would consider it possible, economically rational, and hence preferable, to adopt on a sustainable basis a course of action on the market aimed at selling at increased prices" ${ }^{28}$ There are three key conditions for coordinated effects: a high market concentration so that firms can be aware of each others' actions; an ability to respond to price changes swiftly, in order that deviant behaviour can be punished; and weak competitive constraints from entrants or fringe players outside the core group. ${ }^{29}$ In respect of the first criterion, Ofgem quotes high Hirfindahl Hirschman Indices (HHIs), well above the 1800 figure which the OFT regards as highly concentrated ${ }^{30}$ Other market characteristics may also assist coordinated effects. Gas and electricity are homogeneous products and electricity incumbents have similar market profiles (though the gas incumbent's dominance on a national basis gives it a different structure). Crucially, there is repeated interaction between the firms, both in each of the regional electricity markets and in the national gas market and such multimarket contact can facilitate collusion, especially when costs vary between

\footnotetext{
${ }^{27}$ Waterson, M., "The role of consumers in competition and competition policy" (2003) 21(2) International Journal of Industrial Organization 129-150. This is rather surprising since the average bill for electricity is about two thirds of that for gas, but is perhaps explicable because the data were collected from the same survey.

${ }^{28}$ Guidelines on the assessment of horizontal mergers under the Council Regulation on the control of concentrations between undertakings, OJ [2004] C31, 5-18, para.39.

${ }^{29}$ Merger References: Competition Commission Guidelines, CC2 (Competition Commission, London: 2003), pp.30-31.

${ }^{30}$ Ofgem, Domestic Competitive Market Review 2004, Vol. 2 (London: Ofgem, 2004), pp.161-163; OFT, Mergers: substantive assessment guidance, OFT 512 (London: OFT, 2003), p.23. In gas, the figure is falling very slowly but is still above 4,000 (a "numbers equivalent" of 2.5). Most electricity regions have similar HHIs, though the figure rises to nearly 7000 (a "numbers equivalent" of less than 2) in the north of Scotland region. These figures have risen recently because of consolidation between electricity suppliers.
} 
firms in different markets. ${ }^{31}$ As Ofgem recognises, such extensive multimarket contact may also help overcome the difficulties of punishing deviant firms. $^{32}$

We have seen that consumers perceive there to be significant switching costs. The regulatory requirement of publishing tariff information assists transparency in prices, another condition for coordinated effects. While such information may reduce consumers' search costs, it provides information to firms about each other's pricing behaviour. Even the market analyses which the regulator undertakes annually may help the firms understand better the actions of competitors and the implications for themselves. ${ }^{33}$ Moreover prices can be changed quickly, another condition for coordinated effects (in particular, the punishment of deviant firms). ${ }^{34}$

Entry from outside the group of incumbent firms has not been successful over time and, therefore, the threat of entry seems to be only a weak competitive constraint. Moreover, the importance of brand awareness, it seems, is acknowledged by the regulator. ${ }^{35}$ There is, therefore, both theoretical and empirical evidence that these markets may be prone both to abuse of dominant power by incumbents who retain significantly high market shares, and to coordinated effects among firms which interact repeatedly in fifteen closely related markets.

\section{Managing the transition from monopoly to competition}

In this section, we consider the regulatory responses during the transition from monopoly to competitive retail supply markets. We chart the history of the price controls from the time when competition was introduced until their removal in April 2002. There then follows a discussion which explains how and to what extent the incumbents were permitted to respond to competition from new entrants at different stages during this process. Somewhat ironically, the prospect of competition and its advent required for a period more prescriptive price regulation to prevent dominant firms from deterring new entry, and to protect certain consumer groups where switching rates were low. ${ }^{36}$ Tariffs offered by entrants in each market were unregulated.

\footnotetext{
${ }^{31}$ Bernheim, D. and M.D. Whinston, "Multimarket contact and collusive behaviour" (1990) 21(1) RAND Journal of Economics 1-26.

32 Ofgem, cited above fn.30, pp.166 to 169 . While Ofgem concludes here that there is insufficient evidence to suggest that the firms are engaging in tacit collusion, it recognises that the market displays all the characteristics necessary for such collusion to occur.

${ }^{33}$ Examples of government facilitation of anti-competitive behaviour are well recognised in the economic literature, for example see: Albæk, S., P. Møllgaard, and P.B. Overgaard, "Government-assisted oligopoly coordination? A concrete case" (1997) 45(4) Journal of Industrial Economics 429-443; Ordover, J.A. and G. Saloner, , "Predation, Monopolization, and Antitrust", in Schmalensee, R. and R. Willig (eds.), Handbook of Industrial Organization, Volume I (Amsterdam: Elsevier Science Publishers B.V., 1989).

${ }^{34}$ Firms are required to give customers notice within ten days of a price rise.

${ }^{35}$ Ofgem, cited above fn.30, p.168.

${ }^{36}$ The idea that competition increases the complexity of the regulatory task has been observed elsewhere (e.g., Prosser, T., Law and the Regulators (Oxford: Clarendon Press, 1997), p.8.
} 
By way of introduction, two types of ex ante controls can be distinguished: first, those which regulate the pricing levels of dominant firms, thereby preventing the exploitation of consumers in the absence of sufficient competitive constraints; and secondly, those which regulate the pricing practices of firms, addressed to preventing dominant firms from engaging in exclusionary practices which may deter entry or result in an increase in dominance. The distinction is crucial in scoping an appropriate remedy. If the market is characterised by single firm dominance, ex ante control of the second type can act largely as a substitute for the general competition law. An ex ante approach here may yield further benefits: it may provide for both greater certainty in the application of the law and, depending upon the procedural framework, may reduce the costs of regulation. ${ }^{37}$ We return to this point in the conclusion.

\section{(a) The rebalancing of price controls}

As we previously noted, the prospect of competition rendered unsustainable cross-subsidies which the incumbents inherited from their nationalised predecessors. There was little evidence of a response to rebalance prices when the gas incumbent (BGT) expected to remain a monopolist. ${ }^{38}$ Before competition was introduced, the incumbent was subject to a cap on the average revenue raised from all residential tariffs in this market, but with no separate control on individual tariffs. In response to rebalancing, the regulator devised a new price control for the period in which competition was to be established - from April 1997 to March 2000 - with price controls on each of BGT's four tariff categories. ${ }^{39}$ For the electricity retail sector, absolute price caps operated on all of the incumbents' individual tariffs at the time competition was introduced, so the issue of tariff rebalancing did not arise directly until the review of the price caps in April 2000.

From April 2000, price controls on the direct debit tariffs of BGT and the "inarea" electricity incumbents were removed, the regulator being of the view that competitive pressures on the incumbents' direct debit prices obviated the need for consumer protection in these particular sub-markets. Absolute price caps, however, remained for credit and prepayment consumers. While at this time it was the intention that the price caps would be removed altogether from April 2001, the regulator subsequently decided that a further year of price controls was required in order to protect, primarily, prepayment consumers in

\footnotetext{
${ }^{37}$ For a broad discussion of these points in relation to the regulation of utilities in the UK see: Harker, M. "UK Utility Regulation: Licences, Commitment and Judicial Review" (2005) 76(1) Annals of Public and Cooperative Economics 5. The most significant difference in terms of enforcement route - sectoral or Competition Act - is that the latter firms have a full right of appeal on the merits whereas under the sectoral legislation firms have a right of appeal on a point of law only.

${ }^{38}$ Bradley, I and C. Price, "Economic Regulation of Private Monopolies through Price Constraints" (1988) Journal of Industrial Economics 99-106; Giulietti, M. and C. Waddams Price "Incentive regulation and efficient pricing" (2005) 76(1) Annals of Public and Cooperative Economics 121-138.

${ }^{39}$ i.e., Direct Debit, promptPay, Standard and PrePayment. In 1998 the price control was amended to unify Standard and PrePayment tariffs in order to remove any artificial incentive upon BGT to use Prepayment meters rather than less costly methods of debt recovery.
} 
gas and electricity. ${ }^{40}$ As was previously noted, switching rates among prepayment consumers were far lower as compared with consumers on other tariffs, in particular those paying by direct debit. The discounts being offered by new entrants on the prepayment tariffs of the incumbents were relatively low, and in some cases non-existent. There was a more significant reason. At market opening suppliers were entitled to object to a customer transferring to another supplier on the grounds that the customer was in debt ("debtblocking"), giving rise to concerns that some consumers, and in particular the least well-off, were being "locked-in" to (the more expensive) incumbents. ${ }^{41}$ In 1999, Ofgem expressed concern that debt-blocking was being used as a "customer retention strategy" with the consequence that the "[e]xtensive use of debt-blocking facilities is likely to dilute competition and provide opportunities for suppliers to frustrate customers wishing to switch to a competitor". ${ }^{42}$ By the time the 2001 price controls were set to expire, switching rates among prepayment consumers had increased significantly as had the discounts new entrants were able to offer on the incumbents' prepayment tariffs. $^{43}$ That said, in 2004 there was a flurry of enforcement activity against firms who were continuing to block consumers inappropriately. ${ }^{44}$

\section{(b) Establishing competition: the control of the pricing practices of the incumbents}

At the time competition was introduced in both the electricity and gas markets, each retail supply licence contained a condition which provided that a "dominant firm shall not exercise any undue discrimination against any person or class of persons" and shall not set charges which are "unduly onerous" or "predatory". As was explained above, new entrant firms have targeted the consumers thought to be the most profitable, in particular those paying by direct debit. On the announcement in 1994 that competition was to be introduced, and in order to protect its vulnerable markets, BGT began to rebalance its prices within its binding overall average price cap. Direct debit customers saw their prices fall relative to quarterly credit customers and those on prepayment meters.

\footnotetext{
${ }^{40}$ From April 2001, the electricity incumbents were subject to an absolute price control on their credit customers with an additional restriction on the premium which could be charged to prepayment customers over those paying on credit. In gas, BGT's prepayment tariff was subject to a relative price cap which provided for a maximum differential between its prepayment and direct debit tariffs.

${ }^{41}$ Since suppliers can insist on installing a prepayment meter for those who are in debt to the company, a large proportion of these locked-in consumers would be prepayment consumers, facing the highest prices and being the least able either to pay or to switch. While there were administrative procedures in place for the assignment of debt from the old to the new supplier (with the latter's consent), these provisions were rarely used.

${ }^{42}$ Ofgem, Consumers in debt and their Access to the Competitive Market (Ofgem: London, 1999), pp.12-14.

${ }^{43}$ Ofgem had also agreed a way forward on debt-blocking which involved a further pilot scheme for new debt assignment procedures. In February 2004, the pilots resulted in the implementation of a new debt assignment protocol which allows the prepayment consumers to carry with them a debt of up to $£ 100$ on switching suppliers.

${ }^{44}$ Fines were imposed against BGT, Scottish Power, Npower and Powergen. The decisions are available on the Ofgem website (www.ofgem.gov.uk).
} 
This rebalancing gave rise to a number of concerns: the reduction of the potential profitability of new entry in direct debit markets; and the higher prices it imposed on those consumers who were in the less profitable sub-markets (although such a rise in prices may have had the effect of encouraging entry into these very sub-markets). The issue of undue discrimination was raised in several regulatory decisions, including two following on from a complaint by the statutory consumer council. ${ }^{45}$ The gas regulator published three reports (between 1995 and 1998) exploring relative costs and whether the incumbent was indeed practising undue price discrimination as between its different regulated tariffs. Undue discrimination was interpreted as follows:

If the tariffs do not cover the costs directly attributable to each category of customer, there is a clear case of discrimination. In judging an appropriate allocation of the remaining costs there is more room for debate and therefore more room for discretion by [the incumbent]. However, in the context of a price-controlled monopoly business, fairness in the recovery of 'joint' costs is one of the main issues to be addressed." 46

While the regulator found that there was some evidence of discrimination on these criteria, it was not sufficient to be judged "undue". Even after these findings and the introduction of individual price controls, further rebalancing occurred through BGT's under-recovery of permitted revenue. ${ }^{47}$

The approach of the gas regulator to rebalancing was hardly surprising here. Rebalancing towards cost-reflective pricing was a necessary condition for the introduction of competition. Nevertheless, in the context of monopoly supply in some regional markets, the regulator did signal that the issue of fairness in the recovery of costs was an issue of importance.

The issue of price discrimination arose in a different context in the ValuePlus case. $^{48}$

Shortly after the first phase of competition in south west England, BGT announced a new tariff called ValuePlus, available only to direct debit customers in this area, and representing an average saving of around 5.5 per cent against the regulated tariff. ${ }^{49}$ The regulator consulted upon whether this discount was consistent with BGT's licence conditions. This was a particularly important decision since it would determine when and how BGT was able to respond to competition once it was introduced throughout the rest of the country. It also had implications for the "in-area" electricity incumbents and their ability to respond to competition.

\footnotetext{
${ }^{45}$ At the time, the Gas Consumer Council.

${ }^{46}$ Ofgas, Referral by the Gas Consumers Council relating discounts for customers paying by direct debit: The Director General's decision (London: Ofgas, 1995), pp.8-9. As was noted previously, the level of revenue allowed to BGT was not in question, since this was the subject of a separate average revenue setting exercise, merely the relative prices charged within the overall cap.

${ }^{47}$ As might be expected from the differing levels of competition and the discussion above, BGT underrecovered most on its direct debit tariff but priced closest to its tariff cap for prepayment customers (Ofgem, A Review of the Development of Competition in the Domestic Gas Market (London: Ofgem, 1999, pp.13-14).

${ }^{48}$ Ofgas, ValuePlus: British Gas Trading's Pricing to Direct Debit Customers in the South West of England: A Decision Document (London: Ofgem, 1997).

${ }^{49}$ It was subject to a fixed term contract of 12 months and a 28 day notice period while the regulated tariff was subject only to a 7 day notice period.
} 
Subject to the prohibitions on undue discrimination, the gas incumbent was permitted by its licence to set terms which were "reasonably necessary in order to meet established competition". According to Ofgas, "established competition" represented a stage in the transition from BGT's monopoly to effective competition, the latter being synonymous with the absence of dominance. Emphasis was to be placed upon the operation of the market and determined according to: the level of customer awareness and responsiveness to competition; the range of offers and suppliers in the newly opened market; and the prospects for further development of competition. In respect of the last point, the new tariff "should not so reduce prospective profitability that there is a substantial risk of large scale withdrawal and lack of new entry". As far as customer awareness was concerned, research in the phase one market suggested that it was high. ${ }^{50}$ In respect of new entrants and the development of competition, it was noted that there were, at the time ValuePlus was introduced, some eleven new entrants who had been particularly successful at attracting customers (BGT had lost about a quarter of its direct debit customers). ${ }^{51}$ On this basis, the regulator considered that competition was established in this regional direct debit sub-market.

It was then necessary to decide upon whether the tariff was predatory, a view that was held by all but one of the entrants. The licence provided that prices would be predatory where they did "not cover such avoidable costs as they ought reasonably to cover" and had the purpose of, or were likely to have the effect of, unfairly limiting or excluding competition. Ofgas considered there to be no evidence that ValuePlus either represented an attempt to eliminate competition or had such an effect, because all but one of the new entrants retained a price advantage over BGT. Addressing the issue of whether ValuePlus satisfied the "avoidable cost test", Ofgas' starting point was to look to the level of the discount, since BGT's regulated direct debit tariff was set to "yield a satisfactory margin above... attributable costs". BGT's (take-or-pay) wholesale contracts meant that it paid some 5 pence in excess of the market price paid by new entrants; ${ }^{52}$ the difference between BGT's contract price and the market price for gas was apparently viewed as a "sunk cost" and not one, therefore, which could be viewed as "avoidable". 53

Overall, this was a modest discount and a modest decision. With hindsight, what was surprising was that the regulator did not place more emphasis on the impact that the discount had or could have on consumer switching. Although some new entrants claimed that, as a consequence of ValuePlus, they may have encountered more customer resistance to switching, especially

\footnotetext{
${ }^{50}$ Research suggested that 90 per cent of consumers were aware of the competitive market, two thirds had been contacted by at least one new supplier, and around 80 per cent of those who had switched had experienced few difficulties (Ofgas, Gas Competition: Phase 1 - Research study conducted by MORI for Ofgas (London: Ofgas, 1996)).

${ }^{51}$ For credit and prepayment customers the figures were 16 and 12 per cent respectively.

52 When competition was introduced in gas, the incumbent was disadvantaged by long term wholesale contracts which priced gas above the spot price available to entrants. Sources of electricity were sufficiently diverse that there was no such consistent market advantage.

${ }^{53}$ For a detailed discussion of this point and the case more generally see: Ridyard, D. "Regulation of Price Discrimination and Predation by Dominant Firms: Lessons from the Ofgas ValuePlus Decision" in C. McCrudden (ed.) Regulation and Deregulation: Policy and Practice in the Utilities and Financial Services Industries (Oxford: Clarendon, 1999).
} 
in the light of what they regarded to be customers' strong presumption in favour of BGT as the incumbent supplier, the regulator did not appear to be persuaded by this argument. There may well have been some force in it, however, as later research conducted on behalf of the regulator revealed that 60 per cent of gas consumers would need price reductions of at least 10 per cent in order to be persuaded to switch. ${ }^{54}$ Of the eleven new entrants, eight offered discounts of over 10 per cent on BGT's regulated direct debit tariff, while only three did so in respect of ValuePlus. ${ }^{55}$

Taken together, from these decisions taken under the sectoral legislation we begin to see the emergence of clear and explicit principles governing dominant firms' pricing practices. These principles are in turn clearly inspired by the general competition law, but are tailored towards the particular characteristics of a recently liberalised market. The approach of the regulator could not be characterised as heavy-handed: in varying degrees, emphasis was placed upon the effects of the practices in question, taking into account, in particular, consumer switching behaviour, switching rates among particular groups of consumers, and the need to maintain incentives for entry. The regulator was not bound by a jurisprudence developed mainly in the context of intermediate rather than retail markets, the precise application of which is unclear (as we shall see from the next section). Crucially, the regulator was in position to judge and act swiftly in respect of pre-emptive behaviour on the part of incumbents which might have benefits to some consumers in the shortterm, but be to the detriment of all consumers in the long-term because of its effect on the incentives of new firms to enter. It also had the benefit of giving firms - both incumbents and entrants - a degree of certainty over what was permissible in the context of a developing market. It is clearly arguable that this is a feature which is sadly lacking in the deregulated environment, as we discuss in the following section.

\section{The ex post policing of pricing practice under the Competition Act 1998}

In this section, we consider the move away from prescriptive ex ante regulation to ex post policing of emergent competition in these markets, focusing on pricing practices with exclusionary effects. We have seen that control of incumbents' prices through price controls ceased in April 2002. In October 2001, the licence conditions governing the pricing practices of dominant firms also ceased to have effect, with the consequence that the general competition law, in particular the Chapter II prohibition, now takes centre stage in the control of dominant firms' pricing decisions.

As was previously noted, most of the sectoral regulators, including Ofgem, have the power (concurrently with the OFT) to apply the provisions of the Competition Act to their industry sectors. This does beg the question why, if

\footnotetext{
${ }^{54}$ Ofgem, A Review of the Development of Competition in the Domestic Gas Market, London: Ofgem, 1999), p.55. These results confirmed the findings of Giulietti et al. (supra.).

${ }^{55}$ In no part of the decision did Ofgas consider the effect of the additional transaction and contractual costs involved in the ValuePlus tariff, especially the 12 months' fixed term it attracted, although it was noted that the rate of loss of BGT's market share had declined significantly since its introduction.
} 
ex ante regulation (of prices) is no longer deemed necessary, should the sectoral regulators continue to have an enforcement role? It is useful, therefore, to explore briefly the rationale behind concurrent jurisdiction. ${ }^{56}$

By virtue of the regulator's duty to promote competition under the sectoral legislation, there is no clear demarcation between sectoral regulation and the Competition Act. ${ }^{57}$ As was demonstrated in the preceding section, the regulatory responses to full liberalisation of residential supply were largely informed by principles whose provenance derives from the general competition law. ${ }^{58}$ In this regard, making concurrent powers available to the regulators can be characterised as a continuation of deregulation. ${ }^{59}$ Moreover, the specialist knowledge and expertise of a sectoral regulator is a resource which should be harnessed, as Prosser points out:

“...[A] specialist regulator is far more likely to be able to assess the accuracy of information supplied by a company if he or she has already developed expertise in the sector in which it operates. Given the history of the regulators and the central place of market liberalism in their work, there [are] clear advantages in granting them concurrent powers ... so that they can take advantage of their own special expertise..60

Contrary to the preceding point, however, it may be the case that there are deficiencies in expertise on the part of the sectoral regulators in respect of the application of the prohibitions which, by virtue of section 60 of the 1998 Act, mirror closely the EC prohibitions. ${ }^{61}$ A more consistent approach could perhaps be achieved by OFT merely consulting with the regulators, thereby tapping into their specialist knowledge; this is the position under the mergers regime. $^{62}$

\footnotetext{
${ }^{56}$ An account of the arguments for and against is provided by Bloom, M., 'The Impact of the Competition Bill', in Christopher McCrudden (ed.), Regulation and Deregulation, Policy and Practice in the Utilities and Financial Services Industries (Oxford: Clarendon Press, 1999), pp.238-244. For a defence of concurrency, see Prosser, T., 'Competition, Regulators and Public Services' in Rodger and MacCulloch (eds.), The UK Competition Act: A New Era for UK Competition Law (Oxford: Hart, 2000), pp.227-228. 57 This argument clearly influenced Government: "Regulators need to have powers in order to apply competition law in their sectors and to co-ordinate their use of sector specific regulation with those powers. ... [W]e do not believe that a 'bright line' of jurisdiction between the [OFT] and each of the regulators is practicable. We do not want gaps or litigation about whether the [OFT] or a regulator has jurisdiction. Hence, powers have to be exercisable concurrently by the regulator and the [OFT]" (per Lord Simon of Highbury, HL deb, Vol.586, 1355 (3R)).

${ }^{58}$ See Prosser, cited above at fn.56, pp.228-231. For a discussion in a different context see Scott, C., "Deregulation of BT's Pricing and the New Fair Trading Condition" (1996) 7 ULR 176.

${ }^{59}$ It also has the effect of releasing resources and personnel which the OFT would otherwise have to invest in the supervision of the sector (Bloom, cited above at fn.56, pp.239-240).

${ }^{60}$ Prosser, cited above at fn.56, p.231. Lord Borrie, who had been a key adviser on competition policy to the new administration, observed during the passage of the Bill through Parliament: "The privatised utilities were particularly active in lobbying against those provisions in the Bill that gave concurrent jurisdiction in enforcing the new statutory provisions to the specific industry regulators ... . It is not, I think, too cynical to suggest that the opposition of the utilities ...owed something to the fact that these regulators knew these industries in much more close detail than did the OFT" (Borrie, G., "Lawyers, Legislators and Lobbyists - the Making of the Competition Act 1998" [1999] JBL 205, 211).

61 The OFT by contrast had been the competent national authority in respect of the enforcement of the EC prohibitions for a considerable period before the 1998 Act came into effect.

62 Bloom, cited above at fn.56, p.242. For a brief explanation see Prosser, cited above at fn.56, pp.227228. Under the Enterprise Act 2002, the OFT is the competent body with exclusive jurisdiction to decide whether or not a merger should be referred to the Competition Commission. There exists a concordat between the OFT and Ofgem governing the consultation process which occurs between the two offices in the light of an energy merger: see OFT, Mergers: Procedural Guidance, OFT 526 (London: OFT, 2003), para. 5.17.
} 
There is the further possibility of an objection based on a difference of philosophical approaches between OFT and the sectoral regulators: a potential clash of what might be termed a 'regulatory mentality' versus a 'competition mentality' as Bloom notes:

"This concern stemmed from the fact that the regulated markets have required active intervention on an ex ante basis by the regulators because of their generally uncompetitive structures. In contrast, competition authorities consider that intervention in a market is normally only justified where activity is shown to prevent, restrict or distort competition." ${ }^{\prime 63}$

While the Government insisted upon granting the regulators concurrent powers, a number of concessions were made. ${ }^{64}$ In particular, the sectoral duties were ring-fenced so that they did not apply in relation to the exercise of the regulators' competition powers. ${ }^{65}$ This has important implications, not least removing an obligation on the part of Ofgem to have regard particularly to the interests of vulnerable consumers in the application of the 1998 Act. $^{66}$

For the remainder of this section we consider the substantive principles governing the application of the 1998 Act to residential energy supply markets drawing on the regulator's guidelines and upon the relevant jurisprudence. The guidelines, first published in $2001,{ }^{67}$ offer an important window on how the regulator views its ex post policing powers, and the changes to them in $2005^{68}$ offer a further insight into the regulator's view of how competition is developing in energy supply. ${ }^{69}$

The original guidelines noted that it may take some considerable time for sector-specific case law to develop and "the relatively advanced state of energy liberalisation in the UK compared with most other member states of the EC may... mean that the UK is at the forefront of the application of competition law to competitive energy markets". ${ }^{70}$ Ofgem has consistently committed itself to being vigilant in ensuring that dominant firms do not engage in pre-emptive behaviour. ${ }^{71}$ The original guidance concentrated on

\footnotetext{
${ }^{63}$ Bloom, ibid., p.243.

64 The original Competition Bill, while providing for concurrent powers for the sectoral regulators, did allow for them to take into account their sectoral duties in the application and enforcement of the prohibitions, subject to the caveat that they must regard their powers under the 1998 Act as paramount ${ }^{65}$ The Government also committed to the OFT playing a co-ordinating role in the application of competition law both in terms of its substantive interpretation (through guidance) and through a set of rules governing the co-ordination of the use of concurrent powers. The relevant rules and guidance are: The Competition Act 1998 (Concurrency) Regulations (SI 2004/1077); OFT, Concurrent application to the regulated industries (London: OFT, 2004).

${ }^{66}$ In respect of Ofgem, the "ring-fencing" provisions are now contained in: Gas Act 1986, s.4B(3-4) (as amended); Electricity Act 1989, s.3D(3-4) (as amended). For a criticism of the drafting see Prosser, cited above at fn.56, pp.235-236.

${ }^{67}$ OFT and Ofgem, The Competition Act 1998: The Application in the Energy Sector, OFT 428 (London: OFT, 2001). While the document is published by the OFT, it is largely written by Ofgem. Despite having concurrent powers to enforce the 1998 Act, sectoral regulators do not have the formal power to issue guidelines pursuant to it.

${ }^{68}$ OFT and Ofgem, Application in the energy sector, (London: OFT, 2005).

${ }^{69}$ Ofgem, Responses to the energy sector consultation, OFT428a (London: OFT, 2005). For the draft guidelines consulted upon see Ofgem, The Competition Act 1998: Application in the Energy Sector (London: Ofgem, 2004).

${ }^{70}$ OFT and Ofgem, cited above at fn.67, para. 3.3.

${ }^{71}$ OFT and Ofgem, cited above at fn.68, para.3.3; OFT and Ofgem, cited above fn.67, para.3.6.
} 
predatory pricing as the key example of such behaviour. ${ }^{72}$ Defining its approach to predation, Ofgem claimed that it would apply a "relatively strict cost-based test" having particular regard as to whether the undertaking is recovering its "avoidable costs". ${ }^{73}$ The licence condition governing pricing also used the avoidable costs test in assessing whether a pricing decision of a dominant firm was predatory (and the 2001 guidelines represented a continuation of this approach).

Criticisms were made that the avoidable costs test apparently deviated from the approach under EC law to predation. ${ }^{74}$ It is generally recognised, however, that in industries such as utilities where there are high fixed costs and low incremental costs, alternative cost floors may be considered. ${ }^{75}$ Despite the criticisms of inconsistency (and over-inclusiveness), Ofgem nevertheless insisted on the need to maintain the avoidable costs test in the 2005 guidelines, ${ }^{76}$ while at the same time admitting that its approach to abuses in the 2001 guidelines - focusing largely on predation - may have been "too narrow in focus". 77 Nevertheless, the guidelines remain almost silent on what other types of abuses may occur in the domestic supply market. $^{78}$

One potential key issue in pricing is price discrimination between new and old customers. In order for price discrimination to be feasible, it must be possible for the dominant firm to segment the market. In markets where switching costs are significant, such segmentation is possible and, therefore, the question of whether a dominant firm can lawfully price-discriminate between new and old customers (i.e., customers who have switched and those who have not) is of some importance. If this is not permissible, then a price cut to regain (or stem the loss of) market share would have to be generalised across the dominant firm's entire customer base, thereby rendering it a far less profitable strategy.

There is no presumption that discriminatory pricing is abusive. It is generally accepted that it has ambiguous effects on competition and consumer welfare. $^{79}$ There are many good reasons why (above cost) price discrimination should not amount to an abuse under Article 82 (and the

\footnotetext{
${ }_{73}^{72}$ OFT and Ofgem, cited above fn.67, para. 3.28 .

73 ibid., para. 3.29. Avoidable costs were defined as including "elements of costs that are often described as fixed costs that would not be included in a variable cost test" (ibid.).

${ }^{74}$ Ofgem, cited above at fn.69, para.8.1. The Community Courts have established two general cost based tests for this purpose. Where pricing is below average variable cost (AVC), there is a presumption that the pricing is predatory; where pricing is above AVC, but below average total cost, pricing may be predatory where there is evidence to indicate that the undertaking in question intended a competitor to be eliminated (Case C62/86 AKZO Chemie BV v Commisison [1993] 5 CMLR 215; Case C-333/94P Tetra Pak II [1997] 4 CMLR 662).

${ }^{75}$ For example, the long-run incremental cost test may be more appropriate, taking into account total long-run costs (both capital and operating costs, but not common costs) of supplying an additional unit of output (this is the test applied to the UK telecommunications sector: see OFT, Competition Act 1998: The Application in the Telecommunications Sector, OFT 417, (London: OFT, 2000), para.7.8).

${ }^{76}$ OFT and Ofgem, cited above at fn.68, para.3.27.

${ }_{77}$ Ofgem, cited above at fn.69, para. 8.2.

${ }^{78}$ Rather, they concentrate ancillary issues such as unbundling and upstream matters such as limited storability.

${ }^{79}$ For an economic discussion see Armstrong, M. and J. Vickers, "Price Discrimination, Competition and Regulation" (1993) 41 Journal of Industrial Economics 335.
} 
corresponding UK prohibition). ${ }^{80}$ The principal concern is that a court (or indeed a regulator), in seeking to outlaw illegitimate price cutting strategies, will inadvertently catch or deter legitimate forms of price competition with the consequence that consumers may be worse off as a result. ${ }^{81}$

We now turn to the dynamics of price discrimination in a market with switching costs. Switching costs make it more costly for consumers to change supplier, and may affect the behaviour of firms. ${ }^{82}$ The additional costs which existing customers perceive to be involved in switching enable the firm to raise prices to them without them leaving for other suppliers; but this very opportunity makes customers more profitable, once 'captured', and so makes firms more ambitious to recruit customers so that in future they become 'locked-in' by the inertia which switching costs engender. These dual incentives complicate the impact of switching costs on antitrust policy, and the interpretation of the actions of firms which competition authorities may observe in the market. ${ }^{83}$ For example, firms may appear to be charging predatory prices in recruiting new consumers, and excessive prices in exploiting their inertia once recruited. Such consumers may in fact be charged an appropriate price (relative to costs) when considered in the dynamic setting of recruitment/supply over the whole period of the firm's relationship with the consumer.

Turning to the law, even if a dominant firm is pricing above cost, price discrimination per se may amount to an abuse of dominance. ${ }^{84}$ There are a number of EC cases which have involved undertakings targeting discounts or rebates in favour of those consumers who are most likely to switch to a competing supplier. ${ }^{85}$ The leading case is that of Compagnie Maritime Belge

\footnotetext{
${ }^{80}$ For a discussion in respect of discount and rebate schemes see Ridyard, D., "Exclusionary pricing and price discrimination abuses under Article 82 - an economic analysis" (2003) 23(6) ECLR 286-303.

${ }^{81}$ Broadly speaking this is the position in US law under section 2 of the Sherman Act. See in particular: Verizon Communications Inc., v. Law Offices of Curtis V. Trinko, LLP, 124 S.Ct. at 882 ("Mistaken inferences and the resulting false condemnations 'are especially costly, because they chill the very conduct the antitrust laws are designed to protect."'(quoting Matsushita Elec. Indus. Co. v. Zenith Radio Corp., 475 U.S. 574, 594 (1986)); Brooke Group Ltd. v. Brown \& Williamson Tobacco Corp., 509 U.S. 209, 223 (1993) (above cost price predation schemes are "beyond the practical ability of a judicial tribunal to control").

${ }^{82}$ Klemperer shows that if firms are constrained to supply both 'old' and 'new' consumers at the same price, their effect on the competitive behaviour of firms is ambiguous in a dynamic setting (Klemperer, P., "Competition when consumers have switching costs: An overview with applications to industrial organisation, macroeconomics and international trade" (1995) 62 Review of Economic Studies 513539).

${ }^{83}$ See National Economic Research Associates, Switching Costs, Economic Discussion Paper 5 (London: OFT, 2003) for a comprehensive review of the literature and discussion.

${ }^{84}$ While the authorities that exist at EC law involve intermediate rather than retail markets, this distinction does not of itself explain why such pricing practices cannot be caught by Article 82 as a matter of law. Article 82 (and Chapter II) contains a list of illustrative abuses, paragraph (c) referring to "applying dissimilar conditions to equivalent transactions with other trading parties, thereby placing them at a competitive disadvantage". Nevertheless, the general test for an abuse under Article 82 is that a dominant firm is under a "special responsibility" not to distort further a market in which it is dominant (e.g., Case 322/81, Michelin v Commission (1983) ECR 3461, para. 57). It is difficult to see any material distinction between intermediate and final markets since a rebate scheme which "enhances loyalty" does, in the short term at least, benefit the intermediate consumer to whom it is addressed as does an offering from a dominant retail supplier which grants a targeted discount in order to win back a retail consumer who has switched. The material point appears to be whether the targeted discount has (or risks having) an exclusionary effect on the dominant firm's competitors.

85 In the Hilti case, the EC Commission found an abuse where Hilti had identified its competitors' main customers and offered them more attractive discounts than were offered to firms who had remained loyal. Hilti had a market share of between 70 and 80 per cent of the relevant market. The Commission
} 
$v$ Commission where the European Court of Justice held that the targeted use of a pricing strategy to eliminate competition was clearly an abuse even if the prices were not below cost. ${ }^{86}$

This issue has been considered to some extent by the regulator. In 2002, Ofgem published a discussion paper on the use of consumer lock-ins and winback strategies in the domestic electricity supply sector. ${ }^{87}$ Lock-ins typically involve a fixed-term contract with a termination fee in return, for example, for fixed or capped prices over the contract period. It expressed the view that these can create benefits for consumers, namely a reduction of risk and savings (should prevailing prices rise). In respect of win-back offers, used principally by incumbents to attract switching consumers back in return for a discount, Ofgem stated that such strategies can be "a legitimate response to meet vigorous competition". It also thought that consumers may benefit in the short run from significant discounts, and that win-back offers may make customers "less sticky", for example, a customer may be willing to switch to a non-incumbent supplier if there is the prospect of returning to the incumbent at a considerable discount. No mention was made of the legal position in respect of price discrimination between loyal and returning customers which such strategies normally entail. Nor was mention made of what criteria might apply in deciding whether price discrimination of this type might amount to an abuse of a dominant position. An opportunity to address these issues fully did, however, arise in the London Electricity case (the only case concerning an alleged abuse of dominance in the domestic energy supply sector) ${ }^{88}$. A complaint was made against London Electricity (LE), at the time enjoying a 69 per cent share of the domestic electricity supply market in that region. The complainant alleged an abuse of dominance on two grounds. First, that the financial incentive to return to LE was considerably greater than any savings that most suppliers could offer to new customers. Secondly, the requirement to remain with the company for thirteen months was a form of consumer lockin. While LE was engaging in price discrimination (as between new and existing LE customers) which was capable of amounting to abuse, Ofgem held that the price discrimination did not have a material effect on competition

did not attempt to prove that the strategy was one of predatory pricing, and the Court of First Instance upheld this approach agreeing that this was "not a legitimate mode of competition" for a dominant undertaking (Case T-30/89 Hilti AG v Commission [1992] 4 CMLR 16, para.100).

${ }^{86}$ Case C-395/95and 396/95 P, [2000] 4 CMLR 1076, paras. 112-121. This case concerned a liner conference whose members benefited from a block exemption permitting the fixing of shipping rates and schedules for particular services. In the event of a non-member seeking to compete with them,

members would agree and designate "fighting ships" for which lower rates would be quoted to shippers. While not loss-making, the owners of the fighting ships would receive payments from other members of the conference compensating them for any loss of profits. It has been suggested that this decision should be treated with some caution. In particular because the conference liner had a market share of 90 per cent (seen as synonymous with "super-dominance"), had only one competitor, and there was evidence of clear exclusionary intent (Whish, R., Competition Law, 5ed. (London: Butterworths, 2003), p.714).

${ }^{87}$ Ofgem, Electricity supply competition: An Ofgem occasional paper, 83/02 (London: Ofgem, 2002).

${ }^{88}$ Ofgem The Gas and Electricity Market Authority's Decision under the Competition Act 1998 that London Electricity plc has not Infringed the Prohibition Imposed by Section 18(1) of the Act with Regard to a 'Win Back' Offer (London: Ofgem, 2003). Under the terms of the win-back offer, consumers switching back to LE would receive a voucher worth $£ 25$ after four months and another voucher worth a further $£ 50$ after nine months. Although the consumer was entitled to switch at any time, in order to benefit from the full $£ 75$ (s)he would have to remain with LE for 13 months. 
owing to the "severely limited" take-up of the offer. ${ }^{89}$ On this basis Ofgem made a non-infringement decision; it did not explore meaningfully when and how this type of price discrimination might amount to an abuse of dominance.

It is unfortunate that Ofgem did not take this opportunity to address the issue of price discrimination in a formal setting and by reference to the jurisprudence by which it is bound as it is likely to be very significant for the future of competition in energy supply. As was explained above, the retail supply licences are now silent on price discrimination, so reliance must be upon the general competition law. In the light of the dearth of UK case law, particular reliance must be placed on the general guidance and the case law of the Community Courts, but as was seen from the foregoing discussion, the picture remains unclear. These problems are exacerbated further by the current uncertainty over the future approach to Article 82 at the EC level, ${ }^{90}$ a point which Ofgem recognises. ${ }^{91}$

To summarise, the story so far is one of a regulator who has made statements that it will be particularly vigilant to protect against the pre-emptive behaviour of incumbents. Concentrating on predation has, as the regulator admits, resulted in a "narrow" focus. The general trend in prices since competition has been introduced is for incumbents to price above the new entrants and suffer a gradual decline in market share. However, as Ofgem noted, as market share declines the "strategy of trading market share for profit will look increasingly short-sighted" with the consequence that there will come a point where "it will be rational for the incumbent to start competing on price for every customer". ${ }^{92}$ It is worthy of note that despite this prediction, three years later suppliers as incumbents still nevertheless maintain significant mark-ups over suppliers as entrants.

In the light of Ofgem's apparently permissive approach to win-back strategies - which involve price discrimination between consumers who have switched and those that have not - the incumbents will be able to adopt a two-tier strategy in order to retain and perhaps even increase market share: with selective discounts to attract back consumers who have switched away in combination with fixed-term contracts which themselves create switching costs. If price discrimination of this type is permitted, the only requirement that the incumbents need satisfy is that their win-back offers do not offend the avoidable costs test. It may be that the costs of intervention, in particular the potential of dampening vigorous price competition, are too high to warrant an

\footnotetext{
${ }^{89}$ Arguably this was not relevant: in Case T-219/99 British Airways v Commission [2004] CMLR 1008 the $\mathrm{CFI}$ rejected a defence forwarded by British Airways that it had actually lost market share during the existence of a target rebate scheme. In the view of the Commission - which the Court upheld - this argument was irrelevant because British Airways' market share would have been eroded further absent the rebate scheme.

${ }^{90}$ EC Commission, DG Competition Discussion Paper on the Application of Article 82 of the Treaty to Exclusionary Abuses (Brussels: EC Commission, 2005); Economic Advisory Group on Competition Policy, An Economic Approach to Article 82 (Brussels: EC Commission, 2005). For an excellent discussion of the issues, and a criticism of the Commission's response, see: Akman, P., "Article 82 Reformed? The EC Discussion Paper on Exclusionary Abuses" (2006) Journal of Business Law (forthcoming).

${ }^{91}$ Ofgem, cited above at fn.69, para.8.2. [consultation]

92 Ofgem, Domestic gas and electricity supply competition: Recent developments (London: Ofgem, 2003), para.3.16.
} 
intervention under Chapter II. These issues should, however, be addressed by the regulator. Arguably they would have been under the ex ante licence conditions on price discrimination and, since the substantive principles applied there were informed by the general competition law, much the same result would have been yielded (except perhaps where there were particular distributional concerns surrounding vulnerable consumers). ${ }^{93}$ The difference, however, would have been a degree of certainty over what is a legitimate response to competition on price by a dominant firm, a matter which is currently vexing the EC Commission and the antitrust community. Contrary to some of the views of both the firms and others, this sectoral regulator has not displayed a 'regulatory mentality'; arguably the opposite is true. Furthermore, as was discussed previously in this section, practices with ambiguous effects on welfare, such as price discrimination, if controlled should be through focused and certain principles. Where this condition is lacking, there is the danger that the spectre of Chapter II, with its associated uncertainty, will have the effect of dampening vigorous price competition.

\section{Conclusions}

We have traced the evolution of competition in the UK residential energy markets as they have moved from monopoly, through nascent and established competition to (apparently) effective competition. In this period they have been deregulated, in so far as the ex ante regulation of pricing has been replaced by ex post policing of behaviour under the Competition Act 1998. Deregulation is, however, only partial in the sense that the industries retain sectoral regulatory institutions (a regulator and a statutory consumer watchdog).

The regulatory approach has been to see ex ante regulation as a substitute for the consumers' ability to exit. This reflects the traditional paradigm of sectoral regulation as it was first posited by one of its architects, Littlechild:

"[C]ompetition is indisputably the most effective means - perhaps ultimately the only effective means - of protecting the consumers against market power. Regulation is essentially a means of preventing the worst excesses of monopoly; it is not a substitute for competition. It is a means of 'holding the fort' until competition arrives." ${ }^{94}$

As the ability for consumers to switch provider was introduced, so these ex ante controls were removed. Both the regulator's and independent analyses show that while switching continues in these markets, most of the incumbents retain market shares in excess of 50 per cent with substantial mark-ups over entrants, something which would perhaps have drawn these markets to the attention of more general competition authorities in other markets but for the continued jurisdiction of the regulator.

\footnotetext{
${ }^{93}$ Member States may adopt a stricter approach to EC law in restricting or sanctioning unilateral conduct (Regulation (EC) No 1/2003 on the implementation of the rules on competition laid down in Articles 81 and 82 of the Treaty, OJ [2003] L1, 1-25, Art.3 and Recital 8).

${ }_{94}$ Littlechild, S.C., Regulation of British Telecommunications' Profitability (London: HMSO, 1983), para.4.11 (original emphasis).
} 
The regulator propagates a largely optimistic view of competitive forces in these markets on the grounds of the dynamic movement towards competition. It seems reluctant to take a clear and coherent approach to pricing practices with the absence of solid case law and guidance governing the limits of incumbent behaviour. This situation can be contrasted unfavourably with the position existing prior to the full deregulation of pricing. Arguably, the assumption that an ex post approach would be superior to the ex ante approach was flawed on three grounds: first, the ex ante/ex post distinction is one which, in practice, proved to be less significant given the open-textured nature of the licence prohibitions and the effects-based analyses which informed the regulator's approach to decisions; secondly, there were advantages, both to firms (in terms of certainty) and the regulator (in terms of costs), which were sacrificed; and thirdly, and perhaps most importantly, as a result of the uncertainty which exists over how the Chapter II prohibition should be applied, it may well be that firms are being deterred from engaging in more vigorous price competition. We noted in section 3 the fact that these industries display all the hallmarks normally associated with collective dominance, in particular the repeated interaction of six firms who have the position of being both incumbents and entrants. If the foregoing analysis is correct, any (in)action on the part of the regulator may tend to dampen the incentives of firms to compete vigorously and should, therefore, be treated very seriously.

The experiment to deregulate British residential energy markets was a bold one and it seems the outcome is not yet clear. Deregulation of pricing was seen as necessary to implement the experiment fully, and if the regulator's optimism is correct, we could see lower prices, more innovation on the part of suppliers and more choice for consumers as a result. If the worrying signs of dominance and high incumbent prices continue, however, there are real concerns about the effect on consumers who are reluctant to switch providers, and particularly low income and other vulnerable households. This is likely to lead to a greater politicisation of this sector, raising the spectre of tacit regulation. This is of particular concern because, after a long period of decline, real energy prices have risen sharply (in gas, exceeding prices at privatisation). ${ }^{95}$ Such price rises will have a disproportionate impact on low income households because they devote a higher proportion of their expenditure to these products. The outcome of this experiment, and the role of the regulatory institutions, both formal and informal, will provide important lessons for other countries contemplating opening their own residential markets to competition in the coming years and, in particular, the EU-15 Member States who are committed to do so by July $2007 .{ }^{96}$

\footnotetext{
${ }^{95}$ Ofgem, Domestic Retail Market Report - March 2006 (London: Ofgem, 2006), p.11.

${ }^{96}$ For a discussion see Harker, M. "New developments in the European liberalisation of domestic energy markets" (2002) JBL 323. In June 2005, the EC Commission opened a sector inquiry into the gas and electricity markets in the EU. The preliminary results of that inquiry were published in February 2006, with the Commission concluding that there were remaining substantial barriers to a fully functioning internal market in energy and the Commission foreshadowed possible remedies, including the use potentially of its competition enforcement powers (see EC Commission, Preliminary Report - Sector Inquiry under Art.17 Regulation 1/2003 on the gas and electricity markets (Brussels: EC Commission, 2006).
} 